\title{
Nutrients and carbon budgets for the Gulf of Lion during the Moogli cruises
}

\section{Bilans de sels nutritifs et de carbone dans le golfe du Lion pendant les campagnes Moogli}

\author{
Xavier Durrieu de Madron ${ }^{\mathrm{a}, *}$, Lionel Denis ${ }^{\mathrm{b}}$, Frédérique Diaz ${ }^{\mathrm{c}}$, N. Garcia ${ }^{\mathrm{c}}$, Cécile Guieu ${ }^{\mathrm{d}}$, \\ Christian Grenz ${ }^{c}$, Marie-Dominique Loÿe-Pilot ${ }^{\mathrm{e}}$, Wolfgang Ludwig ${ }^{\mathrm{a}}$, Thierry Moutin ${ }^{\mathrm{c}}$, \\ Patrick Raimbault ${ }^{\mathrm{c}}$, Céline Ridame ${ }^{\mathrm{d}}$ \\ ${ }^{a}$ Centre de Formation et de Recherche sur L'Environnement Marin, University of Perpignan, 52, avenue de Villeneuve, 66860 Perpignan, France \\ ${ }^{b}$ Laboratoire d'Océanographie et de Biogéochimie, Centre d'Océanologie de Marseille, 163, avenue de Luminy, 13288 Marseille, France \\ ${ }^{c}$ Station Marine de Wimereux, University of Lille 1, 28, avenue Foch, 62930 Wimereux, France \\ ${ }^{d}$ Laboratoire d'Océanographie de Villefranche/Mer, Observatoire Océanologique de Villefranche-sur-Mer, 06234 Villefranche-sur-Mer, France \\ e Unité de Biogéochimie Marine, Ecole Normale Supérieure, 1, rue Maurice-Arnoux, 92120 Montrouge, France
}

Received 14 February 2001; received in revised form 28 June 2002; accepted 4 July 2002

\begin{abstract}
Shelf-slope exchanges and budgets of organic and inorganic nutrients are calculated for the Gulf of Lion continental margin in the northwestern Mediterranean. Computations are based on data from three seasonal marine surveys performed in March 1998, June 1998 and January 1999 in the framework of the French Programme National d'Environnement Côtier. A Land-Ocean Interactions in the Coastal Zone type box model is used to calculate the advective exchanges between the shelf and the adjacent open sea and to estimate the budgets of non-conservative elements (DIP, DIN, DOP, DON, DOC, POC, PON, POP). These budgets consider river discharges, urban sewage supply, atmospheric deposition, and fluxes at the water-sediment and shelf-slope interfaces. Uncertainties on the fluxes and budgets are estimated to assess the robustness of the results with respect to the spatial variability of the system. Results indicate that shelf-slope exchanges by mixing predominate with respect to the major input terms (river discharge and sediment release). Budgets for inorganic nutrients, that show a strong concentration gradient between the shelf and the slope waters, are significantly different from zero and indicate an excess of these elements in the shelf water. For all surveys, these surpluses suggest (i) that the whole shelf system is autotrophic $\left(1.6-4.3 \times 10^{3} \mathrm{~mol} \mathrm{C} \mathrm{s}{ }^{-1}\right)$ and acts as a sink of $\mathrm{CO}_{2}$, and (ii) that it is a site of net denitrification $\left(119 \mathrm{~mol} \mathrm{~N} \mathrm{~s}^{-1}\right)$ and acts as a sink of $\mathrm{N}_{2}$. Average shelf-slope fluxes of dissolved and particulate organic elements generally indicate an export to the open sea. However, the large uncertainty on these fluxes yields budgets for the shelf not significantly different from zero.
\end{abstract}

(C) 2003 Éditions scientifiques et médicales Elsevier SAS and Ifremer/CNRS/IRD. All rights reserved.

\section{Résumé}

Les échanges entre le plateau et l'océan ouvert et les bilans de nutriments organiques et inorganiques ont été estimés pour la marge continentale du golfe du Lion en Méditerranée nord occidentale. Les calculs sont fondés sur les données de trois campagnes de mesure saisonnières réalisées en mars 1998, juin 1998 et janvier 1999 dans le cadre du Programme National d'Environnement Côtier. Un modèle en boîte de type LOICZ a été utilisé pour calculer les échanges advectifs entre le plateau et l'océan ouvert adjacent et pour estimer les bilans d'éléments non-conservatifs (PID, NID, POD, NOD, COD, COP, NOP, POP). Ces bilans prennent en compte les apports des rivières, les effluents urbains, les dépôts atmosphériques, et les flux aux interfaces eau-sédiment et plateau-pente. Les incertitudes sur les flux et les bilans, liée à la variabilité spatiale du système, ont été estimées pour tester la robustesse des résultats. Les résultats indiquent que les échanges plateau-pente par mélange dominent les principales sources (rivière et sédiment). Les bilans pour les nutriments inorganiques, qui présentent

* Corresponding author. Fax: +33-4-68-66-20-96

E-mail address: demadron@gala.univ-perp.fr (X. Durrieu de Madron). 
un important gradient de concentration entre les eaux du plateau et celles de la pente, sont significativement différents de zéro et indiquent un excès de ces éléments sur le plateau. Pour toutes les campagnes, ces excès suggèrent que l'ensemble du système (i) est autotrophique $\left(1.6-4.3 \times 10^{3} \mathrm{~mol} \mathrm{C} \mathrm{s}^{-1}\right)$ et agit comme un puits $\mathrm{CO}_{2}$, et (ii) présente un taux de dénitrification nette de $119 \mathrm{~mol} \mathrm{~N} \mathrm{~s}^{-1}$ et agit comme une source de $\mathrm{N}_{2}$. Les flux moyens des éléments organiques dissous et particulaires entre le plateau et la pente indiquent généralement une exportation vers l'océan ouvert. Cependant, les grandes incertitudes associées à ces estimations ne permettent pas de conclure sur la réalité de cette exportation.

(C) 2003 Éditions scientifiques et médicales Elsevier SAS and Ifremer/CNRS/IRD. All rights reserved.

Keywords: Mediterranean Sea; Shelf-slope exchanges; Ecosystem functioning; Carbon cycle; Nutrients budget

Mots clés : Mer Méditerranée ; Echanges côte-large ; Fonctionnement de l'écosystème ; Cycle du carbone ; Bilan de sels nutritifs

\section{Introduction}

\subsection{Rationales of biogeochemical budgets in coastal areas}

Continental margins, despite their small surface with respect to that of the world ocean, play a significant role in the global biogeochemical cycles of carbon, nitrogen and phosphorus (Liu et al., 2000; Mantoura et al., 1991; Wollast, 1991). Land-derived carbon, particularly the organic forms, may either be respired on the shelf, and thus form a potential source for the atmospheric carbon (Smith and Mackenzie, 1987), or be exported on the shelf and slope sediments supporting the notion of carbon-rich "depocenters" for the continental margins (Walsh et al., 1981; Peng and Broecker, 1984). Besides, the increase input of anthropogenic nutrients (particularly nitrate and phosphate) to the continental shelves may result in an increase in the biological pump-increased primary productivity - and therefore constitute an additional sink for atmospheric carbon dioxide (Walsh et al., 1985; Smith and Mackenzie, 1991). Thus, continental margins form a buffer zone, between the continent and the open sea, where the material of continental origin including that from the anthropogenic activities is caught, transformed and eventually stored or exported to the open sea. International research programs, such as Land-Ocean Interactions in the Coastal Zone (LOICZ) and Joint Global Ocean Flux Study (JGOFS), are devoted among other things to understanding and quantifying the contribution of continental margins to the budget of carbon and associated elements. The main objective is to determine whether continental margins export or import nutrients with the open sea and what is their effect on the carbon cycle in terms of a source or sink of $\mathrm{CO}_{2}$. However, the actual role of ocean margins in the global biogeochemical cycles remains difficult to achieve and it has been still a matter of controversy to state definitively whether coastal zones export or import nutrients with the open sea and they are sources or sinks for carbon dioxide (Kempe, 1995). The knowledge and understanding as well as quantification of the processes occurring at the ocean margins have still to be increased (Wollast and Chou, 2001b). For that purpose, LOICZ and JGOFS planned to quantify vertical and horizontal carbon and nutrients fluxes in different types of continental margins (boundary current, polar, sub-polar, tropical and marginal systems) where nutrients are used as proxies. A box-model budgeting approach was developed by
Gordon et al. (1996) in the framework of LOICZ that allows a straightforward approximation of the nutrients fluxes between the coastal zone and the adjacent open ocean and, consequently, to estimate their budgets.

The Gulf of Lion shelf is a major continental margin of the Mediterranean Sea that receives the input from the Rhone, one of the largest Mediterranean rivers (Unesco, 1993). It has been the subject of intensive physical and biogeochemical oceanographic studies over the last 15 years within the framework of the European Eros (European River Ocean Systems) and the French Ecomarge (ECOSystèmes de Marge continentale) and Programme National d'Environnement Côtier (Pnec) programs (Monaco et al., 1990; Martin and Milliman, 1997). During the 1996-2000 phase, three surveys of the Gulf were made in March, June and January 1998-1999 to provide seasonal snapshots of the physical and biogeochemical structures over the whole margin. Extensive data sets of dissolved and particulate, inorganic and organic nutrients were collected in combination with CTD data and studies of primary and new production (Diaz, 2000; Raimbault, 2000).

This paper assesses the carbon, nitrogen and phosphorus fluxes on the Gulf of Lion' continental shelf based on these three surveys. First, it provides a robust quantification of the flow of nutrients across the system boundaries, using an adapted form of the LOICZ box-model approach, so as to quantify the nutrients budgets on the shelf and hence to characterize its role as a net source or sink for carbon, nitrogen and phosphorus. Second, it interprets these budgets to gain evidence on ecosystem functioning and its seasonal variability. This work complement a preliminary study, based solely on dissolved nitrogen and phosphorus, performed within the framework of LOICZ (Durrieu de Madron et al., 2001), as well as carbon budgets (Durrieu de Madron et al., 2000; Sempéré et al., 2000) and biogeochemical models (Pinazo et al., 1996; Tusseau-Vuillemin et al., 1998; Diaz, 2000) for this area.

\subsection{Description of the study area}

The Gulf of Lion $\left(42-44^{\circ} \mathrm{N}, 3-6^{\circ} \mathrm{E}\right)$ has a large crescentshaped continental shelf (Fig. 1). More than 10 rivers with a total watershed area of about $125000 \mathrm{~km}^{2}$ deliver significant water discharges into the gulf. The Rhone river on the northwestern part of the gulf delivers about $90 \%$ of the total 


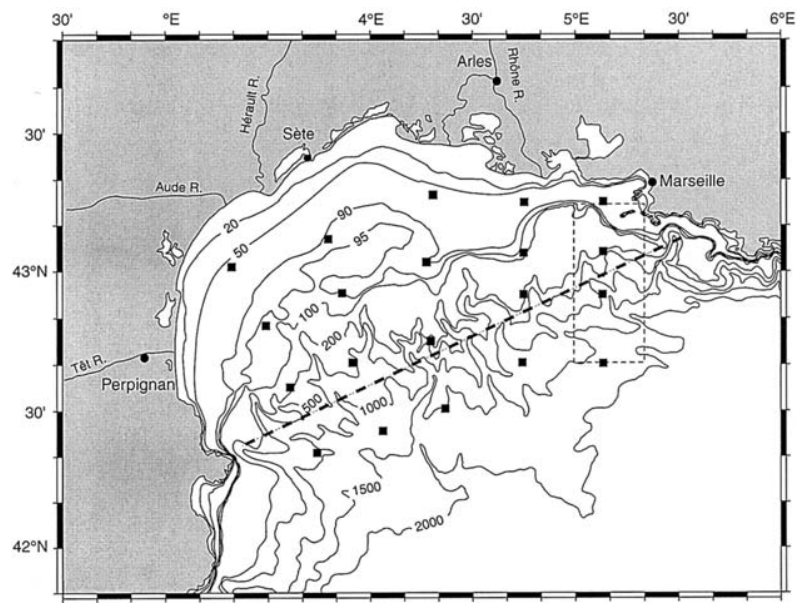

Fig. 1. Map of the Gulf of Lion with the stations network used to build the budgets. The shelf region is delimited by the $150 \mathrm{~m}$ isobath. The thick dashed line delineates the shelf stations from the open sea stations. The thin dotted line offshore of Marseille is the region of ADCP measurements compiled during 1997-2000.

riverine water inputs. The shoreline is heavily urbanized (ca. 1.5 million inhabitants), with one of the largest French city, Marseilles (800 000 residents), at the northeastern tip of the shelf. Terrestrial sources of nutrients from sewage treatment waters, runoff and rivers, bring significant supply of nutrients in the form of nitrate and phosphate to the Gulf. Minas and Minas (1989) showed that the Rhone river inputs enhance significantly the primary productivity on the shelf. Aerosols transported to the Gulf of Lion consist of anthropogenic-rich "background" materials supplied continuously from the nearby land, upon which sporadic pulses of Saharan terrigenous dust are superimposed (Chester et al., 1989). Inorganic nitrogen is almost entirely anthropogenic (industrial combustion and vehicle traffic) and contributes to new production (Loÿe-Pilot et al., 1990). Lithogenic inorganic phosphorus may represent half of total atmospheric deposition but the question of its solubility and bioavailability is still open (Ridame and Guieu, 2002).

The system has a large open boundary between the shelf waters and the slope waters offshore. Strong gradients of salinity and nutrients are usually located near the shelfbreak, delineated by the $150 \mathrm{~m}$ isobath. A strong cyclonic boundary current, that comprises the northern branch of the general circulation in the western Mediterranean, transports large amount of nutrients (Conan et al., 1998). Whereas the main outer branch permanently flows southwestward along the slope (water flux about $1-2 \times 10^{6} \mathrm{~m}^{3} \mathrm{~s}^{-1}$ ), shallow flows occasionally penetrate over the shelf under the effect of wind (Millot, 1990; Estournel et al., 2003) and current instabilities (Flexas et al., 2002; Petrenko, 2003). The mesoscale variability of the currents induces an exchange of inorganic and organic elements between the ocean and the shelf, that is rather well represented by a mixing (turbulent diffusion) term (e.g. Durrieu de Madron et al., 1999).

A well-marked seasonality results from surface heat fluxes. In summer, the solar heating of the surface layer causes the formation of a seasonal thermocline around 20$40 \mathrm{~m}$ depth. In winter, cold and continental winds as well as air-sea temperature differences induce an important evaporation and heat loss from the sea. The sustained cooling and mixing of the surface layer lead to a relative homogenization of the water column and the formation of dense waters on the shelf that cascade down the slope. This latter process was not observed during the winter/spring surveys, but is considered as a major export mechanism (Tusseau-Vuillemin et al., 1998; Béthoux et al., 2003). The upward transport of nutrient by vertical mixing in winter explains the relative importance of primary productivity rates in the Gulf of Lion compared to those generally measured in the Mediterranean Sea (Diaz et al., 2000).

\section{Models and observations}

\subsection{Modeling approach}

Biogeochemical modeling according to the LOICZ approach (Gordon et al., 1996) was applied to estimate the exchange patterns at the boundaries of the coastal system. This box-modeling approach considers that the system over the period of interest is at steady state. Given that the inputs of water and dissolved material to the system are known, the model uses the water volume and salt conservation within the system to infer the exchanges with the adjacent open ocean. For the conservative water budget, we consider river discharge, sewage discharge, precipitation, evaporation, and mixing flow and residual flow at the boundary with the open ocean. For the conservative salt budget, only the cross-shelf exchanges are taken into account. The budget of the nonconservative dissolved elements (nutrients, dissolved and particulate organic matter) on the shelf results from inputs by river, sewage and atmospheric deposition as well as exchanges with the open ocean, and the sediment. Additional output terms are considered for particulate organic matter: fish landing for POC, PON and POP, and sediment burial for POC.

We chose the classical LOICZ single box system to describe the unstratified water column and the dynamics observed during wintertime, from November to early May. As the system later changes to a stratified water column, we developed a modified version of the LOICZ two-layer system to improve the description of the mixing flow between the shelf and the open ocean during summertime, from June to October. Both models are described in Appendix A. The shelf system has a surface area of $12000 \mathrm{~km}^{2}$, and a total volume of $9.1 \times 10^{11} \mathrm{~m}^{3}$. While the shelf has a sloping bottom down to $200 \mathrm{~m}$, the average depth for the one-layer model is about $76 \mathrm{~m}$. For the two-layer models the surface layer thickness is $30 \mathrm{~m}$, and the deep layer average depth is $46 \mathrm{~m}$. 
Table 1

Mean values and 95\% confidence interval of freshwater discharges, precipitation, evaporation, residual and mixing fluxes for three surveys in the Gulf of Lion. Confidence intervals are statistically estimated confidence interval of each parameters derived from the series of observations. Italic type confidence intervals are an approximation to the corresponding standard deviation. Positive and negative numbers represent inflow and outflow, respectively

\begin{tabular}{llll}
\hline Parameters & January 1999 & March 1998 & June 1998 \\
\cline { 3 - 3 } & & & Surface layer \\
River discharge $V_{\mathrm{Q}}\left(\mathrm{m}^{3} \mathrm{~s}^{-1}\right)$ & $2330 \pm 470$ & $1360 \pm 270$ & $1570 \pm 320$ \\
Sewage discharge $V_{\mathrm{O}}\left(\mathrm{m}^{3} \mathrm{~s}^{-1}\right)$ & $5 \pm 1$ & $5 \pm 1$ & $5 \pm 1$ \\
Precipitation $V_{\mathrm{P}}\left(\mathrm{m}^{3} \mathrm{~s}^{-1}\right)$ & $220 \pm 40$ & $40 \pm 10$ & $12 \pm 2$ \\
Evaporation $V_{\mathrm{E}}\left(\mathrm{m}^{3} \mathrm{~s}^{-1}\right)$ & $-630 \pm 130$ & $-510 \pm 100$ & $-380 \pm 80$ \\
System salinity $S_{\mathrm{syst}}$ & $38.08 \pm 0.07$ & $37.91 \pm 0.08$ & $37.73 \pm 0.12$ \\
Ocean salinity $S_{\mathrm{ocn}}$ & $38.29 \pm 0.10$ & $38.16 \pm 0.13$ & $38.02 \pm 0.03$ \\
\hline
\end{tabular}

\subsection{Data}

\subsubsection{Fluxes of freshwater and nutrients from the continent}

Extensive water flux data are available for the Gulf of Lion rivers, from the Compagnie Nationale du Rhone and the Hydro data bank of the French Ministry of Environment (Table 1). Dissolved inorganic nitrogen and phosphorus (DIN, DIP) concentrations are available for all rivers for the last 20 years. Organic nitrogen and phosphorus (DON, DOP, PON, POP) concentrations are available during the period of the cruises only for the Rhone river. Organic carbon concentrations (DOC, POC) were not measured during the period of the cruises, but were estimated from the predictive equations of Sempéré et al. (2000). The Rhone river concentrations were used to extrapolate the river fluxes of organic nutrients from all rivers (Tables 2-4).

Significant discharges of treated sewage effluent occur at Marseilles. Although the water volume of sewage is small relative to other freshwater inputs, total $\mathrm{N}$ and $\mathrm{P}$ are highly concentrated in the effluent (data from the Service d'Assainissement of city of Marseilles, personal communication). We used the following stoichiometric ratios between the dissolved inorganic and total fractions: DIN/TN $=0.38$ and DIP/TP $=0.5$ (San Diego-McGlone et al., 2000) to estimates discharges coefficients (water: $0.3 \mathrm{~m}^{3} \mathrm{~d}^{-1} \mathrm{pm}^{-1}$; DIP: 19 mmol d ${ }^{-1} \mathrm{pm}^{-1}$; DIN: $419 \mathrm{mmol} \mathrm{d}^{-1} \mathrm{pm}^{-1}$ ). Sewage discharges to the sea by the total population living along the coast (1.5 million, 1999 data from the French National Institute for Statistics and Economic Studies) were estimated using the latter discharge coefficients (Tables 2-4).

In the LOICZ approach, nutrients and organic matter from rivers and treated sewage are assumed to have a conservative behavior during the mixing process between unsalted and salted waters. However, this assumption is not confirmed especially for the DIP inputs in the Rhone river; Moutin et al. (1998) suggested that the quantity of the bio-available phosphorus may be significantly lower in the salt water than in the Rhone waters due to the precipitation of the incoming orthophosphate iron and calcium oxides. Accordingly, the nutrient fluxes from rivers to the shelf computed in this paper may be overestimated, particularly that of DIP.

\subsubsection{Freshwater and nutrients fluxes at the air-sea interface}

Evaporation and precipitation are estimated from a highresolution re-analysis of the ECMWF model outputs made by the Cerfacs in Toulouse (data from Siefridt et al., personal communication). The net balance of precipitation and evaporation is negative throughout the year, with rainfall decreas-

Table 2

Mean values and 95\% confidence interval of non-conservative nutrient inputs and concentrations for January 1999 (Moogli 3 cruise in the Gulf of Lion). Confidence intervals are statistically estimated standard deviations of the parameters derived from the series of observations. Italic type confidence intervals are an approximation to the corresponding confidence interval (NA, data not available)

\begin{tabular}{|c|c|c|c|c|c|c|c|c|}
\hline Parameters & DIP & DIN & DOP & DON & DOC & POC & PON & POP \\
\hline $\begin{array}{l}\text { River fluxes } V_{\mathrm{Q}} Y_{\mathrm{Q}} \\
\left(\mathrm{mmol} \mathrm{s}^{-1}\right)\end{array}$ & $5400 \pm 1080$ & $330840 \pm 66170$ & $2650 \pm 530$ & $98850 \pm 19770$ & $381620 \pm 76320$ & $273480 \pm 54700$ & $6960 \pm 1370$ & $980 \pm 200$ \\
\hline $\begin{array}{l}\text { Sewage fluxes } V_{\mathrm{O}} Y_{\mathrm{O}} \\
\left(\mathrm{mmol} \mathrm{s}^{-1}\right)\end{array}$ & $350 \pm 70$ & $7300 \pm 1460$ & NA & NA & NA & NA & NA & NA \\
\hline $\begin{array}{l}\text { Atmospheric deposition } \\
V_{\text {atm }} Y_{\text {atm }}\left(\mathrm{mmol} \mathrm{s}^{-1}\right)\end{array}$ & $60 \pm 60$ & $17360 \pm 17360$ & NA & NA & $22000 \pm 4000$ & $10000 \pm 10000$ & NA & NA \\
\hline $\begin{array}{l}\text { Benthic fluxes } V_{\text {sed }} Y_{\text {sed }} \\
\left(\mathrm{mmol} \mathrm{s}^{-1}\right)\end{array}$ & $300 \pm 2060$ & $4830 \pm 14150$ & NA & NA & NA & NA & NA & NA \\
\hline $\begin{array}{l}\text { Sediment burial } V_{\text {bur }} Y_{\text {bur }} \\
\left(\mathrm{mmol} \mathrm{s}^{-1}\right)\end{array}$ & NA & NA & NA & NA & NA & $492000 \pm 156000$ & NA & NA \\
\hline $\begin{array}{l}\text { Fish landing } V_{\mathrm{fl}} Y_{\mathrm{fl}} \\
\left(\mathrm{mmol} \mathrm{s}^{-1}\right)\end{array}$ & NA & NA & NA & NA & NA & $2060 \pm 410$ & $410 \pm 82$ & $30 \pm 6$ \\
\hline $\begin{array}{l}\text { System concentration } \\
Y_{\text {syst }}\left(\mathrm{mmol} \mathrm{m}^{-3}\right)\end{array}$ & $0.02 \pm 0.01$ & $2.03 \pm 0.21$ & $0.07 \pm 0.01$ & $4.96 \pm 0.27$ & $66.84 \pm 6.07$ & $4.42 \pm 1.07$ & $0.53 \pm 0.13$ & $0.028 \pm 0.007$ \\
\hline $\begin{array}{l}\text { Ocean concentration } Y_{\text {syst }} \\
\left(\mathrm{mmol} \mathrm{m}^{-3}\right)\end{array}$ & $0.12 \pm 0.08$ & $4.19 \pm 1.87$ & $0.09 \pm 0.02$ & $4.23 \pm 0.74$ & $65.91 \pm 15.81$ & $2.58 \pm 0.34$ & $0.33 \pm 0.11$ & $0.015 \pm 0.005$ \\
\hline
\end{tabular}


Table 3

Mean values and 95\% confidence interval of non-conservative nutrient inputs and concentrations for March 1998 (Moogli 1 cruise in the Gulf of Lion). Confidence intervals are statistically estimated standard deviations of the parameters derived from the series of observations. Italic type confidence intervals are an approximation to the corresponding confidence interval (NA, data not available)

\begin{tabular}{|c|c|c|c|c|c|c|c|c|}
\hline Parameters & DIP & DIN & DOP & DON & DOC & POC & PON & POP \\
\hline $\begin{array}{l}\text { River fluxes } V_{\mathrm{Q}} Y_{\mathrm{Q}} \\
\left(\mathrm{mmol} \mathrm{s}^{-1}\right)\end{array}$ & $2350 \pm 470$ & $183660 \pm 36730$ & $850 \pm 170$ & $43380 \pm 8680$ & $167760 \pm 33550$ & $42260 \pm 8450$ & $5970 \pm 1190$ & $810 \pm 160$ \\
\hline $\begin{array}{l}\text { Sewage fluxes } V_{\mathrm{O}} Y_{\mathrm{O}} \\
\left(\mathrm{mmol} \mathrm{s}^{-1}\right)\end{array}$ & $350 \pm 70$ & $7300 \pm 1460$ & NA & NA & NA & NA & NA & NA \\
\hline $\begin{array}{l}\text { Atmospheric deposition } \\
V_{\mathrm{atm}} Y_{\mathrm{atm}}\left(\mathrm{mmol} \mathrm{s}^{-1}\right)\end{array}$ & $60 \pm 60$ & $17360 \pm 17360$ & NA & NA & $4000 \pm 1000$ & $10000 \pm 10000$ & NA & NA \\
\hline $\begin{array}{l}\text { Benthic fluxes } V_{\text {sed }} Y_{\text {sed }} \\
\left(\mathrm{mmol} \mathrm{s}^{-1}\right)\end{array}$ & $1620 \pm 3400$ & $30100 \pm 49970$ & NA & NA & NA & NA & NA & NA \\
\hline $\begin{array}{l}\text { Sediment burial } V_{\text {bur }} Y_{\text {bur }} \\
\left(\mathrm{mmol} \mathrm{s}^{-1}\right)\end{array}$ & NA & NA & NA & NA & NA & $492000 \pm 156000$ & NA & NA \\
\hline $\begin{array}{l}\text { Fish landing } V_{\mathrm{ff}} Y_{\mathrm{fl}} \\
\left(\mathrm{mmol} \mathrm{s}^{-1}\right)\end{array}$ & NA & NA & NA & NA & NA & $2060 \pm 410$ & $410 \pm 82$ & $30 \pm 6$ \\
\hline $\begin{array}{l}\text { System concentration } \\
Y_{\text {syst }}\left(\mathrm{mmol} \mathrm{m}^{-3}\right)\end{array}$ & $0.03 \pm 0.01$ & $1.33 \pm 0.24$ & $0.08 \pm 0.01$ & $4.40 \pm 0.21$ & $85.44 \pm 8.43$ & $6.42 \pm 1.06$ & $0.73 \pm 0.13$ & $0.039 \pm 0.006$ \\
\hline $\begin{array}{l}\text { Ocean concentration } Y_{\text {syst }} \\
\left(\mathrm{mmol} \mathrm{m}^{-3}\right)\end{array}$ & $0.11 \pm 0.09$ & $2.25 \pm 0.44$ & $0.09 \pm 0.02$ & $4.28 \pm 0.30$ & $85.43 \pm 9.37$ & $4.57 \pm 1.43$ & $0.58 \pm 0.08$ & $0.030 \pm 0.010$ \\
\hline
\end{tabular}

ing during summer and evaporation decreasing during spring. The evaporation and precipitation water fluxes for the three surveys are presented in Table 1.

Dry and wet atmospheric deposition of inorganic nitrogen for the Gulf of Lion region were measured in 1988-1989 within the Eros program (Alarcon and Cruzado, 1990; LoÿePilot et al., 1991, 1993; Guieu, 1991). Atmospheric deposition of total phosphorus without local influence has been measured at the atmospheric sampling station of Ostriconi in Corsica in 1999-2000. The DIP flux was estimated to represent $20 \%$ of the total atmospheric deposition (Ridame, 2001;
Ridame and Guieu, 2002). This percentage is probably underestimated because a fraction of the dry deposition of anthropogenic origin will dissolve in seawater; to date, no data are available to quantify this dissolution. Atmospheric deposition of nutrients is summarized in Tables 2-4.

As the inputs of atmospheric POC and DOC are undocumented near the Gulf of Lion, we estimated the total POC deposition (wet + dry) from measurements during 2 years in Corsica (Loÿe-Pilot et al., 1992) where the mean annual POC fallout was about $25 \mathrm{mmol} \mathrm{C} \mathrm{m}^{-2}$ per year, the concentration of DOC in rain water being about $0.1 \mathrm{mmol} \mathrm{l}^{-1}$. For the Gulf

Table 4

Mean values and 95\% confidence interval of non-conservative nutrient inputs and concentrations for June 1998 (Moogli 2 cruise in the Gulf of Lion). Confidence intervals are statistically estimated standard deviations of the parameters derived from the series of observations. Italic type confidence intervals are an approximation to the corresponding confidence interval (NA, data not available)

\begin{tabular}{|c|c|c|c|c|c|c|c|c|}
\hline Parameters & DIP & DIN & DOP & DON & DOC & POC & PON & POP \\
\hline $\begin{array}{l}\text { River fluxes } V_{\mathrm{Q}} Y_{\mathrm{Q}} \\
\left(\mathrm{mmol} \mathrm{s}^{-1}\right)\end{array}$ & $2190 \pm 440$ & $133370 \pm 26670$ & $2800 \pm 560$ & $44100 \pm 8820$ & $237640 \pm 47530$ & $99120 \pm 19820$ & $10050 \pm 2010$ & $1990 \pm 400$ \\
\hline $\begin{array}{l}\text { Sewage fluxes } V_{\mathrm{O}} Y_{\mathrm{O}} \\
\left(\mathrm{mmol} \mathrm{s}^{-1}\right)\end{array}$ & $350 \pm 70$ & $7300 \pm 1460$ & NA & NA & NA & NA & NA & NA \\
\hline $\begin{array}{l}\text { Atmospheric deposition } \\
V_{\text {atm }} Y_{\text {atm }}\left(\mathrm{mmol} \mathrm{s}^{-1}\right)\end{array}$ & $60 \pm 60$ & $17360 \pm 17360$ & NA & NA & $1200 \pm 200$ & $10000 \pm 10000$ & NA & NA \\
\hline $\begin{array}{l}\text { Benthic fluxes } V_{\text {sed }} Y_{\text {sed }} \\
\left(\mathrm{mmol} \mathrm{s}^{-1}\right)\end{array}$ & $2280 \pm 3430$ & $18580 \pm 29690$ & NA & NA & NA & NA & NA & NA \\
\hline $\begin{array}{l}\text { Sediment burial } V_{\text {bur }} Y_{\text {bur }} \\
\left(\mathrm{mmol} \mathrm{s}^{-1}\right)\end{array}$ & NA & NA & NA & NA & NA & $492000 \pm 156000$ & NA & NA \\
\hline $\begin{array}{l}\text { Fish landing } V_{\mathrm{fl}} Y_{\mathrm{fl}} \\
\left(\mathrm{mmol} \mathrm{s}^{-1}\right)\end{array}$ & NA & NA & NA & NA & NA & $2060 \pm 410$ & $410 \pm 82$ & $30 \pm 6$ \\
\hline $\begin{array}{l}\text { System concentration } \\
\text { surface layer } Y_{\text {syst-s }} \\
\left(\mathrm{mmol} \mathrm{m}^{-3}\right)\end{array}$ & $0.003 \pm 0.003$ & $0.01 \pm 0.01$ & $0.07 \pm 0.01$ & $4.52 \pm 0.24$ & $116.68 \pm 9.19$ & $6.30 \pm 0.82$ & $0.80 \pm 0.08$ & $0.031 \pm 0.004$ \\
\hline $\begin{array}{l}\text { Ocean concentration } \\
\text { surface layer } Y_{\mathrm{ocn}-\mathrm{s}} \\
\left(\mathrm{mmol} \mathrm{m}^{-3}\right)\end{array}$ & $0.002 \pm 0.002$ & $0.02 \pm 0.03$ & $0.09 \pm 0.02$ & $4.34 \pm 0.27$ & $111.08 \pm 19.52$ & $7.61 \pm 1.93$ & $0.71 \pm 0.09$ & $0.026 \pm 0.009$ \\
\hline $\begin{array}{l}\text { System concentration } \\
\text { deep layer } Y_{\text {syst-d }} \\
\left(\mathrm{mmol} \mathrm{m}^{-3}\right)\end{array}$ & $0.020 \pm 0.013$ & $0.92 \pm 0.32$ & $0.07 \pm 0.01$ & $4.21 \pm 0.32$ & $97.94 \pm 8.67$ & $3.16 \pm 0.90$ & $0.53 \pm 0.12$ & $0.028 \pm 0.006$ \\
\hline $\begin{array}{l}\text { Ocean concentration } \\
\text { deep layer } Y_{\text {ocn-d }} \\
\left(\mathrm{mmol} \mathrm{m}^{-3}\right)\end{array}$ & $0.160 \pm 0.050$ & $3.83 \pm 1.14$ & $0.06 \pm 0.02$ & $3.99 \pm 0.68$ & $85.47 \pm 9.47$ & $3.37 \pm 1.91$ & $0.39 \pm 0.19$ & $0.022 \pm 0.009$ \\
\hline
\end{tabular}


of Lion, this leads to a POC input of about $1.0 \times 10^{4} \mathrm{mmol}$ $\mathrm{s}^{-1}$. Atmospheric DOC input for the three field surveys ranged between $0.12 \times 10^{4}$ and $20.0 \times 10^{4} \mathrm{mmol} \mathrm{s}^{-1}$ (Tables 2-4). Input of POC and DOC are low in comparison to the riverine inputs.

\subsubsection{Salinity and nutrients observations in the water column}

Three field surveys of the Gulf (March, June 1998 and January 1999) yielded extensive data sets of dissolved inorganic and organic nitrogen and phosphorus concentrations, and particulate organic matter (POC, PON and POP) values in combination with CTD data and estimates of primary and new production (Diaz, 2000; Raimbault, 2000). Salinity and nutrient data were depth-averaged at each station for the different layers considered. Only data shallower than $150 \mathrm{~m}$ depth are used since exchanges between the shelf and the slope occur mainly within this layer. The data were then horizontally averaged separately for the shelf region and the slope region. Salinity values are summarized in Table 1 and nutrient concentrations for each survey are summarized in Tables 2-4.

\subsubsection{Nutrients fluxes at the sediment-water interface}

Flux of nutrients at the sediment-water interface was measured at the shelf stations for the three surveys using the whole core incubation technique based on the rate of concentration change in the overlying water versus time (Denis, 1999; Denis et al., 2001). Each core with non-significant correlation $(P<0.05)$ was considered as zero flux. Triplicated or quadrupled measurements for each station took into account the patchy distribution of benthic organisms and organic matter. Release of inorganic nitrogen and phosphorus from the sediment was observed over the whole shelf area. The shelf-integrated values for benthic release of DIP and DIN are summarized in Tables 2-4.

\subsubsection{Burial of particulate organic matter in the shelf sediments}

Secular mass accumulation rates of sediment on the continental shelf, compiled and mapped by Durrieu de Madron et al. (2001), outline the major sedimentary units of the system (i.e. Rhone prodelta, mid-shelf mud belt, outer shelf). From the average organic carbon content in the surficial sediments of the different units, these authors estimated a burial rate of POC of $49.2 \pm 15.6 \times 10^{4} \mathrm{mmol} \mathrm{s}^{-1}$ for the whole shelf.

\subsubsection{Export of particulate organic matter by fish landing}

Yearly statistics for the French Mediterranean fishery production are compiled by Ofimer (Office national interprofessionnel des produits de la mer et de l'aquaculture). Harbors of the Gulf of Lion received $90 \%$ of the fish landing, which remains stable over the last 5 years. Sardines, anchovies and hake are the most common species and their catches represent about two third of the total weight, that is about $2.4 \times 10^{4}$ tons per year (2001 statistics). The corresponding output of the principal organic constituents, i.e. POC, PON and POP, is estimated using proximate water content (75\%) and stoichiometric composition of fish organic matter (POC: 13\%, PON: $3 \%$ and POP: $0.5 \%$; percentages given are for dry weight) (Huss, 1995; Lyle and Elliott, 1998).

\subsubsection{Vertical shear of the cross-slope current variance at the shelfbreak}

The intensity of the cross-slope current variance at the shelfbreak within the two layers of the stratified two-layer model (0-30 and 30-150 m, see Appendix A) is estimated from the compilation of 4400 current profiles measured offshore of Marseilles with the Acoustic Doppler Current Profiler (ADCP) of the R/V Tethys II. The profiles (between 8 and $244 \mathrm{~m}$ depth) were obtained from November 1997 to May 2000 within a sector (10' longitude and 2.5' latitude) centered at $42^{\circ} \mathrm{N}$ and $5^{\circ} \mathrm{E}$ around the shelfbreak (Fig. 1). The variance of the cross-slope $(\mathrm{N}-\mathrm{S})$ current component decreases exponentially with depth. The average variance was $5.4 \times 10^{4} \mathrm{~cm}^{2} \mathrm{~s}^{-2}$ for the surface layer $(0-30 \mathrm{~m})$ and $2.2 \times$ $10^{4} \mathrm{~cm}^{2} \mathrm{~s}^{-2}$ for the deep layer (30-150 m).

\subsection{Evaluation of uncertainties}

The calculation of exchange flows and the imbalance of non-conservative elements contains uncertainties about the fluxes and concentrations. The uncertainty of any function, $f$, of $N$ independent variables, $x_{i}$, is calculated from the relation:

$$
\delta f=\left(\sum_{i=1}^{N}\left(\frac{\partial f}{\partial x_{i}}\right)^{2}\left(\delta x_{i}\right)^{2}\right)^{1 / 2}
$$

where $\delta x_{i}$ is the uncertainty of the variable $x_{i}$. The uncertainty is defined as the $95 \%$ confidence interval, which defines an interval about the calculated results within which the value of the measurement can be confidently asserted to lie.

For salinity and non-conservative element concentration in the water column, the uncertainty of the measure at each station is small compare to that of the spatial variability. Consequently, we considered only the uncertainty due to the spatial variability over the shelf and ocean regions. In contrast, the benthic fluxes at each station were highly variable. The uncertainty on the benthic fluxes integrated over the shelf region is estimated from measured variances at each sampling point. In absence of direct estimates for the remaining variables, we consider a fixed relative uncertainty. The uncertainty for the freshwater fluxes (river and sewage inputs, precipitation and evaporation) and fish landing is assumed to be $\pm 20 \%$ of the mean flux. Given the high variability of the monthly-averaged atmospheric deposition, this uncertainty is assumed to be $\pm 100 \%$ of the mean annual flux. 


\begin{tabular}{lllll}
\hline & January 1999 & March 1998 & June 1998 & Deep layer \\
\cline { 4 - 5 } & & & Surface layer & \\
Water fluxes & & & $(-1.21 \pm 0.33) \times 10^{3}$ & $(0.11 \pm 0.04) \times 10^{6}$ \\
Residual flux $V_{\mathrm{R}}\left(\mathrm{m}^{3} \mathrm{~s}^{-1}\right)$ & $(-1.93 \pm 0.49) \times 10^{3}$ & $(-0.90 \pm 0.29) \times 10^{3}$ & $(0.07 \pm 0.02) \times 10^{6}$ & \\
Horizontal mixing flux $V_{\mathrm{X}}\left(\mathrm{m}^{3} \mathrm{~s}^{-1}\right)$ & $(0.35 \pm 0.22) \times 10^{6}$ & $(0.14 \pm 0.09) \times 10^{6}$ & & $1.6 \pm 0.8$ \\
Vertical mixing flux $V_{\mathrm{Z}}\left(\mathrm{m}^{3} \mathrm{~s}^{-1}\right)$ & & & & $33 \pm 18$ \\
Non-conservative nutrient fluxes & & & $-0.01 \pm 0.02$ & $-0.1 \pm 0.3$ \\
DIP $\left(10^{4} \mathrm{mmol} \mathrm{s}^{-1}\right)$ & $3.5 \pm 3.6$ & $1.1 \pm 1.4$ & $0.07 \pm 0.2$ & $-2 \pm 9$ \\
DIN $\left(10^{4} \mathrm{mmol} \mathrm{s}^{-1}\right)$ & $75 \pm 81$ & $12 \pm 11$ & $0.1 \pm 0.2$ & $-141 \pm 154$ \\
DOP $\left(10^{4} \mathrm{mmol} \mathrm{s}^{-1}\right)$ & $0.7 \pm 0.9$ & $0.1 \pm 0.3$ & $-2 \pm 2$ & $2 \pm 24$ \\
DON $\left(10^{4} \mathrm{mmol} \mathrm{s}^{-1}\right)$ & $-26 \pm 32$ & $-2 \pm 5$ & $-50 \pm 147$ & $-1.6 \pm 2.6$ \\
DOC $\left(10^{4} \mathrm{mmol} \mathrm{s}^{-1}\right)$ & $-45 \pm 590$ & $-8 \pm 172$ & $-0.7 \pm 0.8$ & $-0.07 \pm 0.1$ \\
POC $\left(10^{4} \mathrm{mmol} \mathrm{s}^{-1}\right)$ & $-65 \pm 57$ & $-26 \pm 30$ & $-0.04 \pm 0.07$ & \\
PON $\left(10^{4} \mathrm{mmol} \mathrm{s}^{-1}\right)$ & $-7 \pm 7$ & $-0.1 \pm 0.2$ & \\
POP $\left(10^{4} \mathrm{mmol} \mathrm{s}^{-1}\right)$ & $-0.5 \pm 0.4$ & &
\end{tabular}

\section{Results and discussion}

The estimated shelf-slope exchanges of water and elements are reported in Table 5 and the budgetary analysis is presented in Table 6.

\subsection{Shelf-slope exchanges}

The Gulf of Lion' shelf has a low residual export volume compared to the large mixing exchanges between the shelf and the slope regions. A sensitivity analysis indicated that most of the uncertainty on the residual flow reflected uncertainty about river input. The large uncertainty about the mixing transport was due essentially to the salinity gradient between the shelf and the slope regions.

Shelf-slope exchanges predominate in winter and were about $10 \%$ of the along-slope water transport (ca. $2 \times 10^{6}$ $\mathrm{m}^{3} \mathrm{~s}^{-1}$ ). Mixing exchanges decreased by three to sixfold for the spring and summer surveys. This seasonal trend with maximum exchanges during winter agrees with the measured variability of along-slope current. Durrieu de Madron et al. (1999) and Lapouyade and Durrieu de Madron (2001) showed from annual to multi-annual current records that the mesoscale variability of the surface and deep currents on the slope has a clear seasonal signal with maximum fluctuations during winter, which favors the cross-slope exchanges of matter.

The exchange time of water in the shelf system can be calculated simply as

$$
\tau=\frac{\mathrm{VS}}{\left(\left|V_{r}\right|+V_{x}\right)}
$$

Where VS $\left(=9.1 \times 10^{11} \mathrm{~m}^{3}\right)$ is the volume of the shelf water and $\left|V_{r}\right|+V_{x}$ is the total flow across the shelf-ocean boundary. Thus, the residence time of the shelf water is between 1 and 2 months.

The exchange fluxes predicted by the box model (despite large uncertainty values) generally indicate that the shelf area acts as a sink for dissolved inorganic nutrients, and as a source to the offshore waters for most of the organic matter (Table 5).

During the winter surveys, the DOP flux showed an opposite trend to those of other organic matter. This suggests that the Gulf of Lion acts during the winter period as a net sink for both DOP and DIP, and, it is worthwhile to note that the model reproduces the peculiar status of the phosphorus elsewhere observed over the whole shelf, where a severe phosphorus depletion was systematically detected in the shelf waters relative to those of the slope during the winter-early spring (Diaz, 2000; Diaz et al., 2001). The riverine inputs, mainly from the Rhone river have very low phosphorus content with a $\mathrm{N}$ to $\mathrm{P}$ ratio of about 78 (Table 4) which is far greater than the classical Redfield ratio (Redfield et al., 1963); this latter feature probably increases the phosphorus depletion in the Gulf of Lion. In this sense, the special status of phosphorus in this Mediterranean area is very similar to that observed in several major marginal seas such as the

Table 6

Estimates (and 95\% confidence interval) of non-conservative nutrient budgets for three surveys in the Gulf of Lion. Positive and negative numbers represent an excess and a deficit in the system, respectively

\begin{tabular}{|c|c|c|c|c|}
\hline \multirow[t]{2}{*}{ Nutrient budgets } & \multirow[t]{2}{*}{ January 1999} & \multirow[t]{2}{*}{ March 1998} & \multicolumn{2}{|l|}{ June 1998} \\
\hline & & & Surface layer & Deep layer \\
\hline$\overline{\Delta \mathrm{DIP}}\left(10^{4} \mathrm{mmol} \mathrm{s}^{-1}\right)$ & $4.1 \pm 3.6$ & $1.5 \pm 1.5$ & $0.4 \pm 0.2$ & $1.7 \pm 0.9$ \\
\hline$\Delta \mathrm{DIN}\left(10^{4} \mathrm{mmol} \mathrm{s}^{-1}\right)$ & $111 \pm 82$ & $36 \pm 13$ & $24 \pm 7$ & $26 \pm 19$ \\
\hline$\Delta \mathrm{DOP}\left(10^{4} \mathrm{mmol} \mathrm{s}^{-1}\right)$ & $1.0 \pm 0.9$ & $0.2 \pm 0.3$ & $0.4 \pm 0.2$ & $-0.1 \pm 0.3$ \\
\hline$\Delta \mathrm{DON}\left(10^{4} \mathrm{mmol} \mathrm{s}^{-1}\right)$ & $-16.6 \pm 32.0$ & $2.3 \pm 5.2$ & $-0.2 \pm 4.9$ & $0.4 \pm 9.5$ \\
\hline$\Delta \mathrm{DOC}\left(10^{4} \mathrm{mmol} \mathrm{s}^{-1}\right)$ & $-5 \pm 593$ & $9 \pm 171$ & $-200 \pm 217$ & $33 \pm 222$ \\
\hline$\triangle \mathrm{POC}\left(10^{4} \mathrm{mmol} \mathrm{s}^{-1}\right)$ & $-86 \pm 59$ & $-70 \pm 34$ & $-10 \pm 26$ & $-18 \pm 36$ \\
\hline$\Delta \mathrm{PON}\left(10^{4} \mathrm{mmol} \mathrm{s}^{-1}\right)$ & $-6.4 \pm 7.4$ & $-1.5 \pm 2.5$ & $-2.2 \pm 2.2$ & $0.8 \pm 3.3$ \\
\hline$\Delta \mathrm{POP}\left(10^{4} \mathrm{mmol} \mathrm{s}^{-1}\right)$ & $-0.4 \pm 0.4$ & $-0.05 \pm 0.2$ & $0.1 \pm 0.1$ & $-0.04 \pm 0.1$ \\
\hline
\end{tabular}


South China sea basin (Chen et al., 2001), in the Northern Baltic sea (Lignell et al., 1992) and in the Bay of Biscay, Northeastern Atlantic (Herbland et al., 1998).

During the early-summer survey, the surface layer of the shelf becomes a net source for DIP to the slope waters and a net sink for POC. These features are in line with field measurements showing the shelf area as a preferential site for the regenerative processes particularly during summer (Diaz, 2000). In the deep layer, the model predicts nutrient exchanges between the slope and shelf waters different from those of the surface layer: for example, more DIN and DIP are imported than exported from the slope to the shelf in the deep layer. This import is in a ratio of 20:1 (DIN:DIP), typical of that found for deep Mediterranean water (McGill, 1969). The model result is in accordance with the observations of LIW upwelling on the shelf in early summer (Minas and Minas, 1989; Conan and Pujo-Pay, 1995). The estimated net export of DOP to the slope water suggests that the deep layer may be a preferential zone for POP remineralization.

The model results on the organic carbon fluxes (i.e. the shelf acts as a source of DOC) are also consistent with recent field observations (Diaz, 2000) that reveal a large DOC accumulation over the shelf in spring and summer followed by a winter decline. While the results are based on short term surveys, the calculated nitrate fluxes accord with those obtained across an annual cycle (Tusseau-Vuillemin et al., 1998) using a biogeochemical model coupled with a general circulation model. The daily estimates of the net advective flux across the margin boundary, which includes the continental slope, indicate that for most of the time the Gulf of Lion acts as a sink of oceanic nitrate. Furthermore, TusseauVuillemin et al. (1998) calculated net nitrate fluxes across the oceanic boundaries of the Gulf of Lion for two different periods of about $330 \mathrm{~mol} \mathrm{~s}^{-1}$ (0.4 thousands of tons of $\mathrm{N}-\mathrm{NO}_{3}$ per day), which are of the same order of magnitude as those estimated by the box model. Similarly, the export of POC estimated for the winter survey $\left(650 \mathrm{~mol} \mathrm{~s}^{-1}\right)$ is comparable to the export estimated by Lapouyade and Durrieu de Madron (2001) from comparison of the inflow and outflow of the Northern Current across a hydrological section encompassing the Gulf of Lion (1040 $\left.\mathrm{mol} \mathrm{C} \mathrm{s}^{-1}\right)$. Moreover, the two earlier studies showed that the margin acts as a source of nitrate and particulate matter to the open sea mainly in winter, during events of dense shelf water cascading that washes out in the shelf water towards the intermediate or deep slope waters. These latter features, and especially those concerning the net export of particulate matter to the shelfslope, have been recently found in the general functioning of several major continental margins such as the northern Gulf of Biscaye (Wollast and Chou, 2001a, b), the East China Sea continental shelf (Chen and Wang, 1999) and the Middle Atlantic Bight (Biscaye et al., 1994). It is worth noting that the winter (January 1999) survey took place a few weeks before a huge event of dense shelf water cascading down the slope and across the whole western Mediterranean deep basin (Béthoux et al., 2003) that entrained about $1.8 \times 10^{5} \mathrm{~m}^{3}$ $\mathrm{s}^{-1}$ of water during 1 month.

\subsection{Balance of non-conservative materials and air-sea exchanges implications}

Non-conservative DIP and DIN fluxes, as well as dissolved and particulate organic phosphorus (DOP, POP), nitrogen (DON, PON) and carbon (DOC, POC) fluxes, were calculated using the estimated volume transports. Fluxes of non-conservative elements are dominated by river inputs, sediment release and shelf-ocean mixing fluxes. Only budgets for DIP, DIN, and occasionally for DOP are significantly different from zero. A sensitivity analysis indicated that most of the uncertainty arose from term for the shelf-slope mixing transport, which in turn relates to the shelf-slope gradient and the uncertainty of the elemental mean concentration in these regions. This clearly shows that this box-model approach gives better results where strong gradients exist, and that error estimates are essential to avoid misinterpretation of the budgets.

The imbalance of the DIN in the system (Table 6) suggests that either the exchange terms may be missing in the computation of the budget or, more likely, that several biological processes affect the stock of DIN on the shelf. The removal of DIN by the denitrifying bacteria is generally considered as an anaerobic process, i.e. with a low occurrence in oxygenated water column. However, the denitrification process can occur in the shelf sediments (Codispoti, 1995) but also over the water column in some anaerobic microenvironments such as in sinking particulate organic matter (Bianchi et al., 1992) and may account for a relatively high rate (Alldredge and Cohen, 1987). In the Mediterranean Sea and especially in the Gulf of Lion, the plume of the Rhone river with very turbid waters and high DIN concentrations has been shown as a preferential environment for denitrification (Omnes et al., 1996). Also, in the water column of the Gulf of Lion, Michotey and Bonin (1997) measured low denitrification (ca. $\left.100 \mu \mathrm{mol} \mathrm{m}{ }^{-3} \mathrm{~d}^{-1}\right)$ associated with particles, with a peak activity (up to $250 \mu \mathrm{mol} \mathrm{m} \mathrm{m}^{-3} \mathrm{~d}^{-1}$ ) in autumn and barely detectable rates $\left(\sim 2 \mu \mathrm{mol} \mathrm{m}{ }^{-3} \mathrm{~d}^{-1}\right)$ during the summer oligotrophic conditions. Following to the LOICZ procedure (Gordon et al., 1996; Smith and Hollibaugh, 1993), an estimate can be made of net nitrogen metabolism (Nfixationdenitrification) of the system, based on system mass imbalance of dissolved nitrogen ( $\triangle \mathrm{DIN}, \triangle \mathrm{DON})$ and phosphorus $(\triangle \mathrm{DIP}, \triangle \mathrm{DOP})$, and $\mathrm{C}: \mathrm{N}: \mathrm{P}$ stoichiometric assumptions. With the assumption that the dominant primary producer is phytoplankton, a classical Redfield N:P ratio of 16:1 has been used to compute the net nitrogen metabolism (Nfixationdenitrification) of the system, that is negative and around $-119 \mathrm{~mol} \mathrm{~s}^{-1}\left(-0.86 \mathrm{mmol} \mathrm{N} \mathrm{m}{ }^{-2} \mathrm{~d}^{-1}\right)$ across the three surveys (Fig. 2). Considering an annual base and neglecting the seasonal variations, this result implies a maximum value of $0.31 \mathrm{~mol} \mathrm{~N} \mathrm{~m}^{-2}$ per year for the denitrification rate; this latter value is close to the value of $0.137 \mathrm{~mol} \mathrm{~N} \mathrm{~m}^{-2}$ per year found by Wollast (1998) for a global shelf average. The fact 


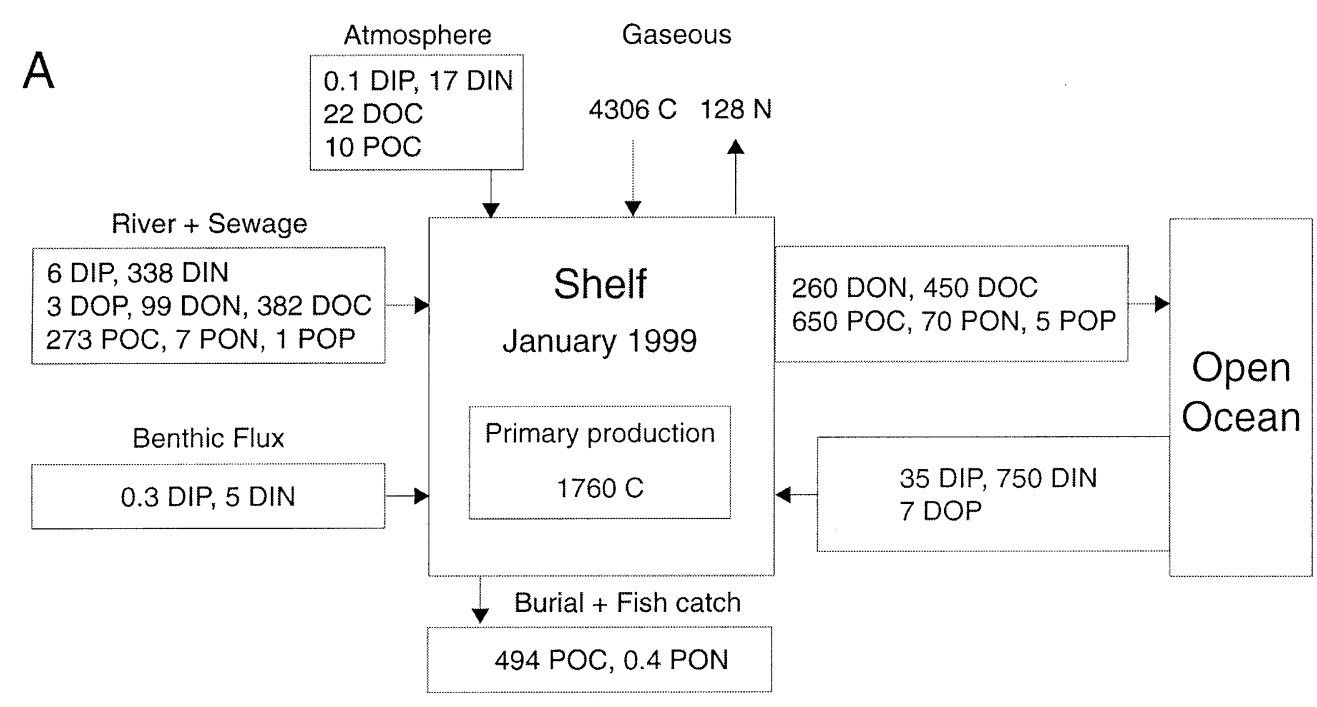

B

Gaseous
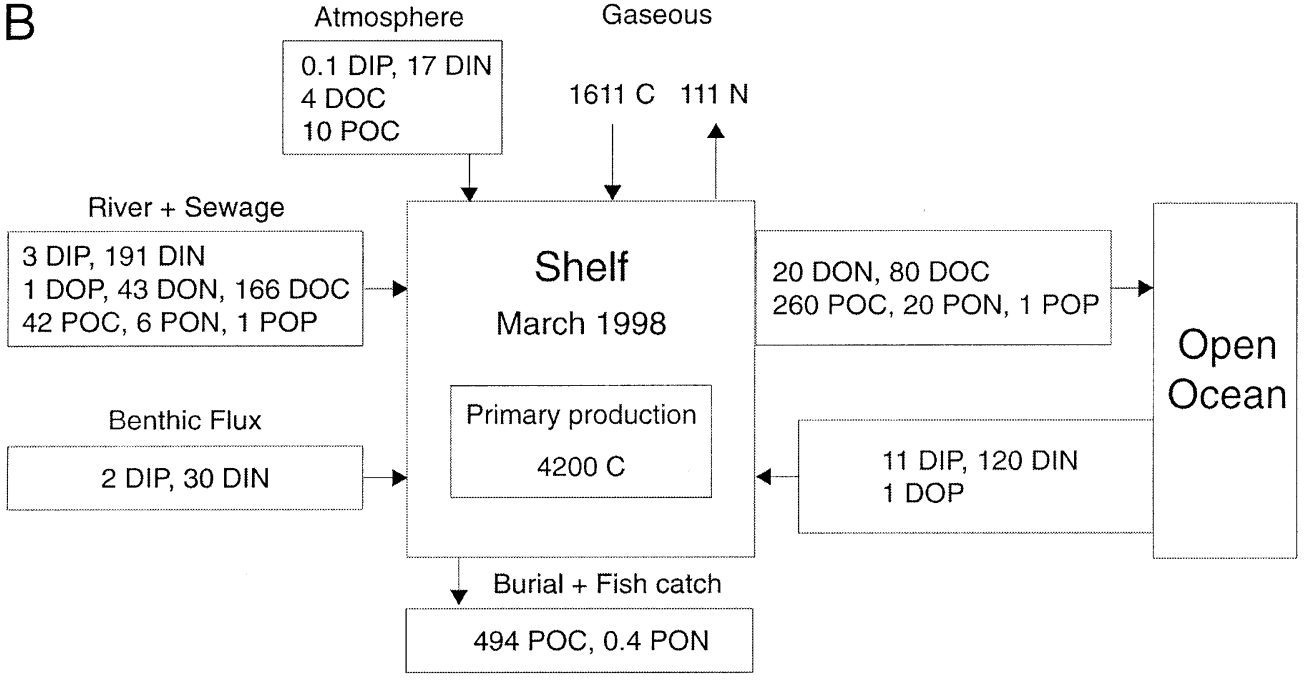

C

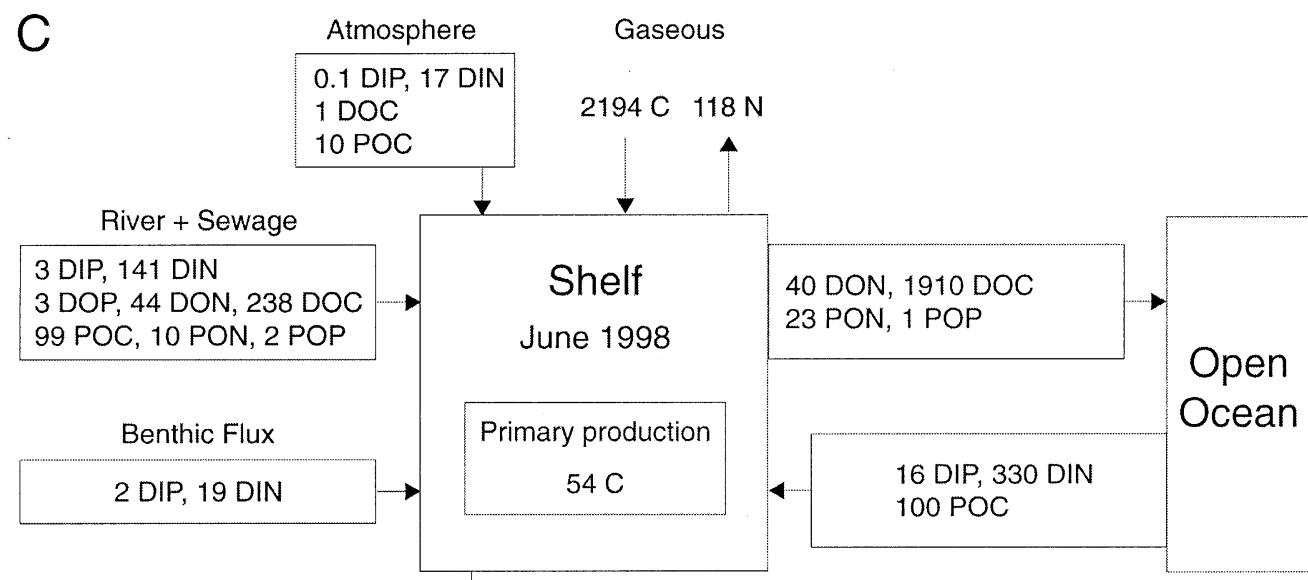

Gaseous

Burial + Fish catch

494 POC, 0.4 PON

Fig. 2. Schematic diagram for the carbon and nutrients budgets (in mol s${ }^{-1}$ ) for three surveys in the Gulf of Lion continental shelf: (A) January 1999, (B) March 1998 and (C) June 1998. Primary production is integrated over the surface of the continental shelf $\left(12000 \mathrm{~km}^{2}\right)$. 
that the denitrification process in the whole shelf slightly dominates the $\mathrm{N}_{2}$ fixation process implies on one hand that the Gulf of Lion systematically acts as a sink for nitrate, on the other hand it suggests that the rates of $\mathrm{N}_{2}$ fixation are of the same order of magnitude as the denitrification rates, i.e. very low in the Gulf of Lion by considering the denitrification measurements performed by Michotey and Bonin (1997).

According to the LOICZ procedure (Gordon et al., 1996; Smith and Hollibaugh, 1993), the calculated mass imbalance of phosphorus $(\triangle \mathrm{DIP})$ with stoichiometric $\mathrm{C}: \mathrm{P}$ ratio for the major primary producer in the system allows an estimate of net ecosystem metabolism (NEM). NEM is more conveniently annotated as $(p-r)$, where $p$ is production and $r$ is respiration. Based on a C:P Redfield ratio of 106:1, the Gulf of Lion was interpreted to be autotrophic by a minimum value of $1610 \mathrm{~mol} \mathrm{C} \mathrm{s}^{-1}\left(11.6 \mathrm{mmol} \mathrm{C} \mathrm{m}^{-2} \mathrm{~d}^{-1}\right)$ for the spring survey to a maximum value of $4306 \mathrm{~mol} \mathrm{C} \mathrm{s}^{-1}$ (31.3 mmol $\mathrm{C} \mathrm{m}^{-2} \mathrm{~d}^{-1}$ ) during the winter survey. An intermediate value of $2194 \mathrm{~mol} \mathrm{C} \mathrm{s}^{-1}\left(15.8 \mathrm{mmol} \mathrm{C} \mathrm{m}^{-2} \mathrm{~d}^{-1}\right)$ was observed during the early summer cruise. This result implies that the study area would be a net producer of organic matter and thus acting as a net sink for $\mathrm{CO}_{2}$. This feature agrees with the review of Gattuso et al. (1998), that indicates that the majority of coastal ecosystems-except estuaries-works as net autotrophic systems on an annual basis. An independent computation of the net metabolism for the shelf waters of the Gulf of Lion recently provided an analogous result (Sempéré et al., 2000). They directly calculated the bacterial respiration in the water column and at the sediment/water interface $\left(8.4 \pm 7.7 \times 10^{10} \mathrm{~mol} \mathrm{C}\right.$ per year $)$ and the total carbon fixed by phytoplankton $\left(13.6 \times 10^{10} \mathrm{~mol} \mathrm{C}\right.$ per year $)$ in the shelf water. Their estimate of the NEM of $5.2 \times 10^{10} \mathrm{~mol} \mathrm{C}$ per year is in accordance with the present calculations, which yield an average value of $8.5 \times 10^{10} \mathrm{~mol} \mathrm{C}$ per year. The most recent estimations of the global coastal NEM vary from $12 \times 10^{12}$ mol C per year (Rabouille, 1997) to about $200 \times 10^{12} \mathrm{~mol} \mathrm{C}$ per year (Wollast, 1998). According to the review of Gattuso et al. (1998), this great range of variation may be essentially due to differences in the estimate of the global respiration term $(r)$. These latter figures combined with those of the present study indicate that the NEM of the Gulf of Lion may represent from $0.05 \%$ to $0.70 \%$ of the global coastal NEM which is a rather large contribution regarding the very small surface of the study area with respect to the total surface of coastal zones.

\section{Conclusion}

Hydrographic and nutrients data collected during three seasonal surveys in the Gulf of Lion indicate that salinity and concentration of most organic and inorganic elements significantly vary between the shelf and the open sea (slope) area. The simple box modeling approach used to calculate the shelf-slope fluxes of water, salt and non-conservative element yields robust results, which are however, subject to large uncertainties.

Results indicate that advective fluxes between the shelf and the open sea have an important influence with respect to the other major inputs (river discharges and sediment release fluxes). Mixing flow at the shelfbreak mainly supports the shelf-slope exchanges. Consequently, the stronger depletion of inorganic nutrients (DIN, DIP) in the shelf waters than in the slope waters leads to a gain for the shelf box, thus providing nutrients to support the local productivity. In summer, the fluxes are significantly reduced. Balancing the DIP budgets suggests that the biological system on the shelf is autotrophic and thus acts as a sink of $\mathrm{CO}_{2}$. The intensity of NEM agrees with that calculated for a previous study. In addition, balancing the DIN budgets suggests that denitrification predominates over nitrogen fixation, and that the system is net denitrifying and thus acts as a source of $\mathrm{N}_{2}$.

Current studies on underground freshwater discharge and the impact of bottom trawling on the shelf will provide an additional input of carbon, nitrogen and phosphorus to the system. This new term will not change the conclusions of the present budgets, because it will a priori reinforce the excess of dissolved inorganic elements (DIN, DIP) on the shelf. Modeling of the dense shelf water formation and cascading over the 1995-2000 period, including the exceptional event of 1999, is underway and will permit assessment of the temporal variability of this export process and its role in the exchanges of water and dissolved elements between the shelf and the open sea. Furthermore, direct measurement of $\mathrm{CO}_{2}$ flux at the ocean-atmosphere interface are presently being made in the Gulf of Lion and will provide a better estimate of the air-sea fluxes as well as the spatial and temporal (seasonal) variability.

\section{Acknowledgements}

The authors wish to thank the support of the Pnec and the European Commission (through the Metro-Med program) for supporting this research. The assistance of the captains and crews of the R/V l'Atalante and le Suroit from Ifremer was greatly appreciated. R. Sempéré and two anonymous reviewers gave constructive criticisms, which strengthened the manuscript.

\section{Appendix A}

\section{A.1. One-layer model}

We briefly summarize the one box model already described by Gordon et al. (1996). For the conservative water budget, we consider river discharge $\left(V_{\mathrm{Q}}\right)$, sewage discharge $\left(V_{\mathrm{O}}\right)$, precipitation $\left(V_{\mathrm{P}}\right)$, evaporation $\left(V_{\mathrm{E}}\right)$, and mixing flow $\left(V_{\mathrm{X}}\right)$ and residual flow $\left(V_{\mathrm{R}}\right)$ at the boundary with the open ocean (Fig. 2A). In the following equations, inflows are 
considered as positive and outflows are considered as negative. The equilibrium between the water inflows and outflows is:

$$
\left(V_{\mathrm{Q}}+V_{\mathrm{O}}+V_{\mathrm{P}}+V_{\mathrm{X}}\right)-\left(V_{\mathrm{E}}+V_{\mathrm{X}}\right)+V_{\mathrm{R}}=0
$$

For the conservative salt budget, only the cross-shelf exchanges are taken into account. The equilibrium between the salt fluxes entering and escaping the system is written:

$$
\left(V_{\mathrm{X}} S_{\text {ocean }}\right)-\left(V_{\mathrm{X}} S_{\text {shelf }}\right)+V_{\mathrm{R}} S_{\mathrm{R}}=0
$$

where $S_{\text {shelf }}$ is the mean shelf salinity, $S_{\text {ocean }}$ the mean open ocean salinity. Because the residual flow can be either out (freshwater inflow exceeding evaporation) or into the system (net evaporation) the appropriate salinity for residual flow is the average salinity between the two systems, $S_{\mathrm{R}}=\left(S_{\text {shelf }}+\right.$ $\left.S_{\text {ocean }}\right) / 2$.

The budget of the non-conservative dissolved element $Y$ on the shelf results from inputs by river $\left(V_{\mathrm{Q}} Y_{\mathrm{Q}}\right)$, sewage $\left(V_{\mathrm{O}} Y_{\mathrm{O}}\right)$ and atmospheric deposition $\left(V_{\mathrm{atm}} Y_{\mathrm{atm}}\right)$ as well as exchanges with the open ocean $\left(V_{\mathrm{X}} Y_{\text {ocean }}, V_{\mathrm{X}} Y_{\text {shelf }}\right.$ and $\left.V_{\mathrm{R}} Y_{\mathrm{R}}\right)$, and the sediment $\left(V_{\text {sed }} Y_{\text {sed }}\right)$. The imbalance $(\Delta Y)$ between the inputs and outputs is:

$$
\begin{aligned}
\Delta Y=\left(V_{\mathrm{Q}} Y_{\mathrm{Q}}+V_{\mathrm{O}} Y_{\mathrm{O}}+\right. & V_{\mathrm{atm}} Y_{\mathrm{atm}}+V_{\text {sed }} Y_{\text {sed }} \\
& \left.+V_{\mathrm{X}} Y_{\mathrm{ocn}}\right)-\left(V_{\mathrm{X}} Y_{\text {syst }}\right)+V_{\mathrm{R}} Y_{\mathrm{R}}
\end{aligned}
$$

Given that the riverine and atmospheric inputs as well as the salinity and dissolved element concentrations are known, the residual and mixing exchanges flows between the shelf and the open ocean are calculated as:

Residual flux:

$$
V_{\mathrm{R}}=V_{\mathrm{E}}-\left(V_{\mathrm{Q}}+V_{\mathrm{P}}+V_{\mathrm{O}}\right)
$$

Mixing flux:

$$
\begin{aligned}
V_{\mathrm{X}} & =-V_{\mathrm{R}} \frac{S_{\mathrm{R}}}{\left(S_{\mathrm{ocn}}-S_{\text {syst }}\right)} \\
& =-\left(V_{\mathrm{Q}}+V_{\mathrm{P}}+V_{\mathrm{O}}-V_{\mathrm{E}}\right) \frac{S_{\mathrm{R}}}{\left(S_{\mathrm{ocn}}-S_{\mathrm{syst}}\right)}
\end{aligned}
$$

Thus the imbalance of non-conservative element is:

$$
\begin{aligned}
\Delta Y=V_{\mathrm{Q}} Y_{\mathrm{Q}}+V_{\mathrm{O}} Y_{\mathrm{O}}+V_{\mathrm{atm}} & Y_{\mathrm{atm}}+V_{\text {sed }} Y_{\text {sed }} \\
& +V_{\mathrm{X}}\left(Y_{\text {ocn }}-Y_{\text {syst }}\right)+V_{\mathrm{R}} Y_{\mathrm{R}}
\end{aligned}
$$

\section{A.2. Two-layers model}

For the stratified system, we developed a two-layer model using the same basic scheme as for the one layer model. For the conservative water budgets in the two layers, we consider river discharge $\left(V_{\mathrm{Q}}\right)$, sewage discharge $\left(V_{\mathrm{O}}\right)$, precipitation $\left(V_{\mathrm{P}}\right)$, evaporation $\left(V_{\mathrm{E}}\right)$, vertical mixing $\left(V_{\mathrm{Z}}\right)$, surface and deep shelf-slope mixing $\left(V_{\mathrm{X}-\mathrm{s}} \mathrm{V}_{\mathrm{X}-\mathrm{d}}\right)$ and residual $\left(V_{\mathrm{R}}\right)$ exchanges. The equilibrium between the water inflows and outflows in the surface layer is:

$$
\left(V_{\mathrm{Q}}+V_{\mathrm{O}}+V_{\mathrm{P}}+V_{\mathrm{X}-\mathrm{s}}+V_{\mathrm{Z}}\right)-\left(V_{\mathrm{E}}+V_{\mathrm{X}-\mathrm{s}}+V_{\mathrm{Z}}\right)+V_{\mathrm{R}}=0
$$

For the deep layer the water balance is described by:

$$
\left(V_{\mathrm{X}-\mathrm{d}}+V_{\mathrm{Z}}\right)-\left(V_{\mathrm{X}-\mathrm{d}}+V_{\mathrm{Z}}\right)=0
$$

For the conservative salt budgets, the surface layer balance is:

$$
\begin{aligned}
& \left(V_{\mathrm{X}-\mathrm{s}} S_{\text {ocn }-\mathrm{s}}+V_{\mathrm{Z}} S_{\text {syst }-\mathrm{d}}\right) \\
& -\left(V_{\mathrm{X}-\mathrm{s}} S_{\text {syst }-\mathrm{s}}+V_{\mathrm{Z}} S_{\text {syst }-\mathrm{s}}\right)+V_{\mathrm{R}} S_{\mathrm{R}}=0
\end{aligned}
$$

The deep layer salt balance is:

$$
\begin{aligned}
& \left(V_{\mathrm{X}-\mathrm{d}} S_{\text {ocn }-\mathrm{d}}+V_{\mathrm{Z}} S_{\text {syst - s }}\right) \\
& \quad-\left(V_{\mathrm{X}-\mathrm{d}} S_{\text {syst }-\mathrm{d}}+V_{\mathrm{Z}} S_{\text {syst - d }}\right)=0
\end{aligned}
$$

The residual and mixing exchanges terms between the shelf and the adjacent open ocean can be calculated if one makes an additional assumption. We hypothesize that the horizontal mixing is proportional to the layer thickness and to the cross-slope current variance. Indeed, Durrieu de Madron et al. (1999) suggested that the turbulent mixing, due to meandering of the Northern Current around the shelfbreak, induces a significant exchange of matter between the shelf and the slope. This mixing can be presented as a function of the current variance in the cross-slope direction. Thus the vertical variation of mixing intensity can be written as:

$$
\frac{V_{\mathrm{X}-\mathrm{s}}}{V_{\mathrm{X}-\mathrm{d}}}=\alpha \frac{H_{\mathrm{s}}}{H_{\mathrm{d}}}
$$

where $H_{\mathrm{s}}$ and $H_{\mathrm{d}}$ are the thickness of the surface and deep layers at the shelfbreak, and $\alpha$ is the ratio of the mean cross-slope current variances between the surface and deep layers.

The imbalance of the non-conservative dissolved element for the surface layer (Fig. 3b) is:

$$
\begin{aligned}
& \Delta Y_{\mathrm{s}}=\left(V_{\mathrm{Q}} Y_{\mathrm{Q}}+V_{\mathrm{O}} Y_{\mathrm{O}}+V_{\mathrm{atm}} Y_{\mathrm{atm}}+V_{\mathrm{X}-\mathrm{s}} Y_{\mathrm{ocn}-\mathrm{s}}\right. \\
& \left.\quad+V_{\mathrm{Z}} Y_{\text {syst }-\mathrm{d}}\right)-\left(V_{\mathrm{X}-\mathrm{s}} Y_{\text {syst }-\mathrm{s}}+V_{\mathrm{Z}} Y_{\text {syst }-\mathrm{s}}\right)+V_{\mathrm{R}} Y_{\mathrm{R}}
\end{aligned}
$$

The imbalance for the deep layer is:

$$
\begin{aligned}
\Delta Y_{\mathrm{d}}=\left(V_{\mathrm{X}-\mathrm{d}} Y_{\text {ocn }-\mathrm{d}}+\right. & \left.V_{\mathrm{Z}} Y_{\text {syst }-\mathrm{s}}+V_{\text {sed }} Y_{\text {sed }}\right) \\
& -\left(V_{\mathrm{X}-\mathrm{d}} Y_{\text {syst }-\mathrm{d}}+V_{\mathrm{Z}} Y_{\text {syst }-\mathrm{d}}\right)
\end{aligned}
$$

The solutions for the residual and mixing flows are:

Residual flux (surface layer):

$$
V_{\mathrm{R}}=V_{\mathrm{E}}-\left(V_{\mathrm{Q}}+V_{\mathrm{P}}+V_{\mathrm{O}}\right)
$$

Horizontal mixing flux (surface layer):

$$
\begin{aligned}
V_{\mathrm{X}-\mathrm{s}} & =\frac{\alpha H_{\mathrm{s}}}{H_{\mathrm{d}}} V_{\mathrm{X}-\mathrm{d}} \\
& =-\frac{V_{\mathrm{R}} S_{\mathrm{R}}}{\left(S_{\text {ocn }-\mathrm{s}}-S_{\text {syst }-\mathrm{s}}\right)+\frac{H_{\mathrm{d}}}{\alpha H_{\mathrm{s}}}\left(S_{\text {ocn }-\mathrm{d}}-S_{\text {syst }-\mathrm{d}}\right)}
\end{aligned}
$$


Horizontal mixing flux (deep layer):

$$
V_{\mathrm{X}-\mathrm{d}}=-\frac{V_{\mathrm{R}} S_{\mathrm{R}}}{\frac{\alpha H_{\mathrm{s}}}{H_{\mathrm{d}}}\left(S_{\text {ocn }-\mathrm{s}}-S_{\text {syst }-\mathrm{s}}\right)+\left(S_{\text {ocn }-\mathrm{d}}-S_{\text {syst }-\mathrm{d}}\right)}
$$

Vertical mixing flux:

$$
\begin{aligned}
& V_{\mathrm{Z}}=V_{\mathrm{X}-\mathrm{d}} \frac{\left(S_{\text {ocn }-\mathrm{d}}-S_{\text {syst }-\mathrm{d}}\right)}{\left(S_{\text {syst }-\mathrm{d}}-S_{\text {syst }-\mathrm{s}}\right)}=- \\
& \frac{V_{\mathrm{R}} S_{\mathrm{R}}\left(S_{\text {ocn }-\mathrm{d}}-S_{\text {syst - d }}\right)}{\left(\frac{\alpha H_{\mathrm{s}}}{H_{\mathrm{d}}}\left(S_{\text {ocn }-\mathrm{s}}-S_{\text {syst - s }}\right)+\left(S_{\text {ocn }-\mathrm{d}}-S_{\text {syst }-\mathrm{d}}\right)\right)\left(S_{\text {syst }-\mathrm{d}}-S_{\text {syst - s }}\right)}
\end{aligned}
$$

Thus, the imbalance of non-conservative element for the surface layer is:

$$
\begin{aligned}
& \Delta Y_{s}=V_{\mathrm{Q}} Y_{\mathrm{Q}}+V_{\mathrm{O}} Y_{\mathrm{O}}+V_{\mathrm{atm}} Y_{\mathrm{atm}}+V_{\mathrm{X}-\mathrm{s}} \\
& \quad\left(Y_{\mathrm{ocn}-\mathrm{s}}-Y_{\text {syst }-\mathrm{s}}\right)+V_{\mathrm{Z}}\left(Y_{\text {syst }-\mathrm{d}}-Y_{\text {syst }-\mathrm{s}}\right)+V_{\mathrm{R}} Y_{\mathrm{R}}
\end{aligned}
$$

Imbalance of non-conservative element (deep layer):

$$
\begin{aligned}
\Delta Y_{\mathrm{d}}=V_{\mathrm{X}-\mathrm{d}}\left(Y_{\text {ocn }-\mathrm{d}}\right. & \left.-Y_{\text {syst }-\mathrm{d}}\right) \\
& -V_{\mathrm{Z}}\left(Y_{\text {syst }-\mathrm{d}}-Y_{\text {syst }-\mathrm{s}}\right)+V_{\text {sed }} Y_{\text {sed }}
\end{aligned}
$$

\section{References}

Alarcon, M., Cruzado, A., 1990. Particulate aerosol nutrient inputs into the Northwestern Mediterranean Sea. EROS 2000 (European river Ocean System) Project Second Workshop. In: Martin, J.M., Barth, H. (Eds.), Water Pollut. Res. Rep, 20. CEC, Brussels, pp. 635-664.

Alldredge, A.L., Cohen, Y., 1987. Can micro-scale chemical patches persist in the Sea? Micro-electrode study of marine snow, fecal pellets. Science 235, 689-691.

Béthoux, J.P., Durrieu de Madron, X., Nyffeler, F., Taillez, D., 2002. Deep water in the western Mediterranean: peculiar 1999 and 2000 characteristics and formation variability since 1970 and geochemical inferences. J. Mar. Syst. 33-34, 117-131.

Bianchi, M., Marty, D., Teyssié, J.L., Fowler, S.W., 1992. Strictly aerobic and anaerobic bacteria associated with sinking particulate matter and zooplankton fecal pellets. Mar. Ecol. Progr. Ser. 88, 55-60.

Biscaye, P., Flagg, C.N., Falkowski, P.G., 1994. The shelf edge exchange processes experiment, SEEP-II: an introduction to hypotheses, results and conclusions. Deep-Sea Res. II 41 (2/3), 231-252.

Chen, C.T.A., Wang, S.L., 1999. Carbon, alkalinity and nutrient budgets on the East China Sea continental shelf. J. Geophys. Res. 104 (C9), 20675-20686.

Chen, C.T.A., Wang, S.L., Wang, B.J., Wand, B.J., Pai, S.C., 2001. Nutrient budgets for the South China Sea basin. Mar. Chem 75, 281-300.

Chester, R., Nimmo, M., Murphy, K.J.T., 1989. Atmospheric inputs of trace metals, trace organics and nutrients to the western Mediterranean-the EROS 2000 Programme. 1st EROS 2000 Workshop, Paris (France), 1989. Water Pollut. Res. Rep., 13, pp. 357-367.

Codispoti, L.A., 1995. Is the losing nitrate? Nature 376, 724.

Conan, P., Pujo-Pay, M., 1995. Estimation of primary production $\left({ }^{14} \mathrm{C}\right)$ in the Gulf of Lions during July 1993. Improvement of a new apparatus for assessing primary production. Water Pollut. Res. Rep. 32, 133-140.

Conan, P., Pujo-Pay, M., Raimbault, P., Leveau, M., 1998. Variabilité hydrologique et biologique au sein du Courant Nord Méditerranéen à l'entrée du golfe du Lion. I. Transports en azote et productivité potentielle. Oceanol. Acta 21, 751-766.
Denis, L., 1999. Dynamique des flux d'oxygène et de sels nutritifs à l'interface eau-sédiment sur la marge continentale du Golfe du Lion (Méditerranée Nord-Occidentale). Ph.D. thesis, University of AixMarseille II, France.

Denis, L., Grenz, C., Alliot, E., Rodier, M., 2001. Temporal variability in dissolved inorganic nitrogen fluxes at the sediment-water interface and related annual budget on a continental shelf (NW Mediterranean Sea). Oceanol. Acta 24 (1), 85-97.

Diaz, F., 2000. Evolution saisonnière de la production primaire et des processus d'assimilation-régénération de l'azote dans le Golfe du Lion. Estimation d'un bilan de carbone. Approches in situ et modélisation. $\mathrm{Ph}$.D. thesis. University of Aix-Marseille II, France.

Diaz, F., Boudjellal, B., Garcia, N., Moutin, T., 2001. Early spring phosphorus limitation of primary productivity in a NW Mediterranean coastal zone (Gulf of Lions. Mar. Ecol. Progr. Ser. 211, 51-62.

Diaz, F., Raimbault, P., Conan, P., 2000. Small-scale study of primary productivity during spring in a Mediterranean coastal area (Gulf of Lions). Cont. Shelf Res. 20 (9), 975-996.

Durrieu de Madron, X., Abassi, A., Heussner, S., Monaco, A., Aloisi, J.C., Radakovitch, O., Giresse, P., Buscail, R., Kerherve, P., 2000. Particulate matter and organic carbon budgets for the Gulf of Lions (NW Mediterranean). Oceanol. Acta 23 (6), 717-730.

Durrieu de Madron, X., Radakovitch, O., Heussner, S., Loÿe-Pilot, M.D., Monaco, A., 1999. Role of the climatological and current variability on shelf-slope exchanges of particulate matter. Evidence from the Rhone continental margin (NW Mediterranean). Deep-Sea Res. I 46, 1513-1538.

Durrieu de Madron, X., Denis, L., Diaz, F., Garcia, N., Guieu, C., Grenz, C., Löye-Pilot, M.D., Ludwig, W., Moutin, T., Raimbault, P., 2001. Coastal systems of France; The western Mediterranean sea. In Coastal and estuarine systems of the Mediterranean and Black Sea regions: carbon, nitrogen and phosphorus fluxes, edited by V. Dupra, S.V. Smith, J.I. Marshall Crossland and C.J. Crossland. LOICZ Reports \& Studies No. 19, LOICZ, Texel The Netherlands, 67-76.

Estournel, C., Durrieu de Madron, X., Marsaleix, P., Auclair, F., Julliand, C., Vehil, R., 2003. Observation and modelisation of the winter coastal oceanic circulation in the Gulf of Lions under wind conditions influenced by the continental orography (FETCH experiment). J. Geophys. Res. 108, C3 in press.

Flexas, M., Durrieu de Madron, X., Garcia, M.A., Canals, M., Arnau, P., 2002. Flow variability in the Gulf of Lions during the MATER HFF Experiment (March-May 1997). J. Mar. Syst. 33-34, 197-214.

Gattuso, J.P., Frankignoulle, M., Wollast, R., 1998. Carbon and carbonate metabolism in coastal aquatic systems. Annu. Rev. Ecol. Syst 29, 405-434.

Gordon Jr, D.C., Boudreau, P.R., Mann, K.H., Ong, J.E., Silvert, W.L., Smith, S.V., Wattayakorn, G., Wulff, F., Yanagi, T., 1996. LOICZ Biogeochemical Modelling Guidelines. LOICZ Reports \& Studies 5. LOICZ, Texel, The Netherlands, pp. 96.

Guieu, C., 1991. Apports atmosphériques à la Méditerranée nordoccidentale. Ph.D. thesis. University of Paris 6, France 225 p.

Herbland, A., Delmas, D., Laborde, P., Sautour, B., Artigas, F., 1998. Phytoplankton spring bloom of the Gironde plume waters in the Bay of Biscay: early phosphorus limitation and food-web consequences. Oceanol. Acta 21 (2), 279-291.

Huss, H.H., 1995. Quality and quality changes in fresh fish. Fao Fisheries Technical Paper-348.

Kempe, S., 1995. Coastal seas: a net source or sink of atmospheric carbon dioxide? LOICZ Reports \& Studies No. 1. Land-Ocean Interactions in the Coastal Zone. Netherlands Institute for Sea Research, Texel, pp. 27.

Lapouyade, A., Durrieu de Madron, X., 2001. Seasonal variability of the advective transport of suspended particulate matter and organic carbon in the Gulf of Lions (NW Mediterranean). Oceanol. Acta 24, 295-312.

Lignell, R., Kaitala, S., Kuosa, H., 1992. Factors controlling phyto- and bacterioplankton in late spring on a salinity gradient in the northern Baltic. Mar. Ecol. Progr. Ser 84, 121-131. 
Liu, K.K., Atkinson, L., Chen, C.T.A., Gao, S., Hall, J., MacDonald, R.W., Talaue McManus, L., Quiñones, R., 2000. Exploring continental margin carbon fluxes on a global scale. EOS transactions. Am. Geophys. Union 81 (52), 641-644.

Loÿe-Pilot, M.D., Martin, J.M., Morelli, J., 1990. Atmospheric input of inorganic nitrogen to the Western Mediterranean. Biogeochemy 9, $117-134$.

Loÿe-Pilot, M.D., Cauwet, G., Spitzy, A., Martin, J.M., 1992. Preliminary results on atmospheric wet deposition of organic carbon and nitrogen in Corsica. EROS 2000 Third workshop on the North Western Mediterranean. In: Martin, J.M., Barth, H. (Eds.), Water Pollut. Res. Rep, 28. CEC, Brussels, pp. 519-532.

Loÿe-Pilot, M.D., Klein, C., Martin, J.M., 1993. Major inorganic elements in North Western Mediterranean aerosols. Concentrations and sources; estimation of dry deposition of soluble inorganic nitrogen. EROS 2000 (European River Ocean System) Project Fourth Workshop. In: Martin, J.M., Barth, H. (Eds.), Water Pollut. Res. Rep., 30. CEC, Brussels, pp. 271-277.

Lyle, A.A., Elliott, J.M., 1998. Migratory salmonids as vectors of carbon, nitrogen and phosphorus between marine and freshwater environments in north-east England. Sci. Total Environ. 210/211, 457-468.

Loÿe-Pilot, M.D., Martin, J.M., Morelli, J., 1991. Atmospheric wet deposition of inorganic nitrogen to the North Western Mediterranean Basin. EROS 2000 (European River Ocean System) Project Second Workshop. In: Martin, J.M., Barth, H. (Eds.), Water Pollut. Res. Rep., 20. CEC, Brussels, pp. 623-634.

Mantoura, R.F.C., Martin, J.M., Wollast, R., 1991. Introduction to the Dahlem workshop. In: Martin, J.M., Wollast, R. (Eds.), Ocean Margin Processes in Global Change. RFC Mantoura, Wiley.

Martin, J.M., Milliman, J.D., 1997. EROS 2000 (European River Ocean System). The western Mediterranean: an introduction. Deep-Sea Res. II 44, 521-529.

McGill, D.A., 1969. A budget for dissolved nutrient salts in the Mediterranean Sea. Cah. Océanogr 21, 543-554.

Michotey, V., Bonin, P., 1997. Evidence of anaerobic bacterial processes in the water column: denitrification and dissimilatory nitrate ammonification in the Northwestern Mediterranean Sea. Mar. Ecol. Progr. Ser 160, $47-56$.

Millot, C., 1990. The Gulf of Lions' hydrodynamics. Cont. Shelf Res 10, 885-894.

Minas, M., Minas, H.J., 1989. Primary production in the Gulf of Lions with considerations to the Rhone River input. Water Pollut. Res. Rep 13, 112-125.

Monaco, A., Biscaye, P.E., Soyer, J., Pocklington, R., Heussner, S., 1990. Particle fluxes and ecosystem response on a continental margin: the 1985-1988 Mediterranean Ecomarge experiment. Cont. Shelf Res 10, 809-839.

Moutin, T., Raimbault, P., Golterman, H.L., Coste, B., 1998. The input of nutrients by the Rhone river into the Mediterranean Sea: recent observations and comparisons with earlier data. Hydrobiologia 373-374, 237-246.

Omnes, P., Slawyk, G., Garcia, N., Bonin, P., 1996. Evidence of denitrification and nitrate ammonification in the River Rhone plume (Northwestern Mediterranean Sea. Mar. Ecol. Progr. Ser 141, 275-281.

Peng, T.H., Broecker, W.S., 1984. Ocean life cycles and the atmospheric $\mathrm{CO}_{2}$ content. J. Geophys. Res. 89 (C5), 8170-8180.

Petrenko, A.A., 2003. Circulation features in the Gulf of Lions, NW Mediterranean Sea; summer versus winter conditions. Oceanol. Acta (this issue).
Pinazo, C., Marsaleix, P., Millet, B., Estournel, C., Vehil, R., 1996. Coupled modelling of physical and biogeochemical proceses in the Gulf of Lions (Northwestern Mediterranean): spatial and temporal variability. J. Mar. Syst. 7, 161-191.

Rabouille, C., 1997. Human perturbation on carbon and nitrogen cycles in the global ocean. Presented at LOICZ Poen Sci. Meeting, 3rd, The Netherlands.

Raimbault, P., 2000. MoOGLI, MOdelisation et Observation du golfe du LIon. Recueil de données. Laboratoire d'Océanographie et de Biogéochimie, Université d'Aix-Marseille II 271 p.

Redfield, A.C., Ketchum, B.H., Richards, F.A., 1963. The influence of organisms on the composition of seawater. In: Hill, M.N. (Ed.), The Sea, Ideas and Observations on Progress in the Study of the Seas. Interscience Publ., New York, pp. 26-49.

Ridame, C., 2001. Rôle des apports atmosphériques d'origine continentale dans la biogéochimie marine: Impact des apports sahariens sur la production primaire en Méditerranée. Ph.D. thesis, University of Paris VI. pp. 246 p.

Ridame, C., Guieu, C., 2002. Saharan input of phosphorus to the oligotrophic water of the open western Mediterranean. Limnol. Oceanogr. 47 (3), 856-869.

San Diego-McGlone, M.L., Smith, S.V., Nicolas, V., 2000. Stoichiometric interpretations of C:N:P ratios in organic waste materials. Mar. Pollut. Bull 40, 325-330.

Sempéré, R., Charrière, B., Van Wambeke, F., Cauwet, G., 2000. Carbon inputs of the Rhone river to the Mediterranean Sea: biogeochemical implications. Global Biogeochem. Cycles 14, 669-681.

Smith, S.V., Mackenzie, F.T., 1991. Comments on the role of oceanic biota as a sink for anthropogenic $\mathrm{CO}_{2}$ emissions. Global Biogeochem. Cycles 5 (4), 189-190.

Smith, S.V., Hollibaugh, J.T., 1993. Coastal metabolism and the oceanic organic carbon balance. Geophys. Rev 31, 75-89.

Smith, S.V., Mackenzie, F.T., 1987. The ocean as a net heterotrophic system: Implications from the carbon biogeochemical cycle. Global Biogeochem. Cycle 1, 187-198.

Tusseau-Vuillemin, M.H., Mortier, L., Herbaut, C., 1998. Modeling nitrate fluxes in an open coastal environment (Gulf of Lions): transport versus biogeochemical processes. J. Geophys. Res. 103 (C4), 7693-7708.

Unesco, 1993. Discharge of selected rivers of the world. Volume II (oart II) Monthly and annual discharges recorded at various selected stations 20-year catalogue (1965-1984). 600.

Walsh, J.J., Premuzic, E.T., Gaffney, J.S., Rowe, G.T., Hartbottle, G., Stoenner, R.W., Balsam, W.L., Betzer, P.R., Macko, S.A., 1985. Organic storage of $\mathrm{CO}_{2}$ on the continental slope off the Mid-Atlantic Bight, the southeastern Bering Sea, and the Peru coast. Deep-Sea Res 32, 853-883.

Walsh, J.J., Rowe, G., Iverson, R., Mc Roy, C., 1981. Biological export of shelf carbon is a sink of the global $\mathrm{CO}_{2}$ cycle. Nature 292, 196-201.

Wollast, R., 1991. The coastal organic carbon cycle: fluxes, sources and sinks. In: Mantoura, R.F.C., Martin, J.M., Wollast, R. (Eds.), Ocean Margin Processes in Global Change. Wiley.

Wollast, R.J., 1998. Evaluation and comparison of the global carbon cycle in the coastal zone and in the open ocean. In: Brink, K.H., Robinson, A.R. (Eds.), The Sea, 10. Wiley, New York, pp. 213-252.

Wollast, R., Chou, L., 2001a. Ocean margin exchange in the northern Gulf of Biscay: OMEX 1. An introduction. Deep-Sea Res 48, 2971-2978.

Wollast, R., Chou, L., 2001b. The carbon cycle at the ocean margin in the northern Gulf of Biscay. Deep-Sea Res 48, 3265-3293. 